\title{
Formação de Técnicos, Cientistas e Pesquisadores
}

Publicou o "Jornal do Comércio", em sua edição de 16 do corrente, um editorial que focaliza, dentre vários assuntos, a necessidade de ser intensiticada, no Brasil, a formação de técnicos, cientistas e pesquisadores.

Êsse editorial, seguro e bem lançado, como costumam ser os daquele grande órgão da imprensa brasileira, precisa ser meditado pelos homens de responsabilidade do país, tal a validez e clarividência de sua arǵumentação.

Subordinando o desenvolvimento econômico de qualquer país à formação de pessoal altamente qualificado, reafirma o decano da imprensa carioca pontos de vista já por nós defendidos em outras oportunidades, e até mesmo reiterados em Editorial (setembro de 1956), quando salientamos que somos um povo pobre - - paupérrimo - de técnicos, que ajudem a assegurar maiot produtividade aos nossos esforços, de onde a premência de favorecer-se a formação e o desenvolvimento de profissionais de categoria superior.

Eis por que julgamos oportuna a transcrição dêsse Editorial, que demonstra, no sólido arcabouço lógico de suas idéias, a importância e gravidade de um problema, já equacionado até mesmo pelos que se acham fora da esfera administrativa.

\section{VÁRIAS NOTÍCIAS}

O lançamento do satélite artificial, ressalvados os efeitos publicitários fartamente explorados pela propaganda comunista, evidenciou os indiscutíveis progressos da pesquisa científica na União Soviética. Essa verificação foi surpreendente apenas para o grende público, pois os meios científicos de todos os países já se encontravam informados das realizações dos técnicos e cientistas soviéticos em diversos ramos do conhecimento. Aliás, essas realizaçóes, embora sejam credorés da admiração universal pelo esfôrço e tenacidade que representam, sòmente nos espíritos apaixonados terão ultrapassado os resultados conseguidos pela experiência e o conhecimento acumulados por sucessivas gerações de pesquisadores em países como a Inglaterra, a França, Alemanha e pela abundância de recursos técnicos e materiais nos Estados Unidos da América.

O progresso científico e técnico alcançado pela Rússia é todavia uma lição eloqüente para países como o Brasil, ansiosos por acelerar o seu desenvolvimento econômico e elevar o padrão de vida de seu povo. No primeiro quartel dêste século, o antigo Império Moscovita, mau grado a abundância 
de recursos naturais em sua vastidão territorial, não ousava confrontar-se com as nações civilizadas no campo da técnica, da ciência e dos empreendimentos materiais. A ampla utilização da técnica e da experiência de outros países, muito mais do que o regime ali implantado, permitiu o racional aproveitamento de recursos naturais, incomparáveis pela variedade e abundância.

Não queremos aqui avaliar o custo social e moral dos sucessos alcançє dos pela Rússia sob a dominação vermelha. A carnificina da guerra civil, a coletivização compulsória da agricultura, o trabalho forçado, a perseguição religiosa, a supressão das liberdades civis, a dominação impiedosa dos países vizinhos, os expurgos periódicos, etc., são integrantes do espantosc sacrifício a que foi submetido o povo russo nestes últimos 30 anos sob a promessa da edificação do paraiso socialista.

O povo brasileiro, acompanhado por todos os povos da civilização ocidental que consideram a dignidade da criatura humana o bem precioso a preservar, não aceitaria nem aceitará o progresso material a preço tão elevado.

Seria, porém, cegueira ou ignorância não querer encontrar na Rússia o apoio à pesquisa e o estímulo ao trabalho técnico e científico. Observadores imparciais, após visitar a Rússia, insistem em salientar êsse aspecțo, ,o qual se vem traduzindo na formação de um grupo selecionado e numeroso de cientistas, pesquisadores e técnicos.

Entre nós, infelizmente, muito pouco se tem feito nesse setor e a pobreza dos recursos oficiais destinados ao ensino técnico e a pesquisa científica contrasta dolorosamente com o desperdício verificado em outros setores. Já se afirmou a possibilidade de medir o progresso de um país pelos recursos postos à disposição de seus Institutos de Tecnologia. Se a afirmação é exata, o nosso atraso é muito grande, pois o Instituto Nacional de Tecnologia vegeta à míngua de dotações orçamentárias e de técnicos e só ainda não pereceu. graças ao esfôrço e à dedicação de um punhado de tecnologistas.

As nossas Universidades, por sua vez, apresentam as maiores deficiências, notadamente no tocante à instalação das Faculdades, seu equipamento técnico e pessoal docente. No que se refere à instalação será suficiente atentar para o desinterêsse dos altos círculos governamentais pelo prosseguimento das obras da Cidade Universitária que, no ritmo atual de execução, aguardará dezenas de anos para a respectiva conclusão. Quanto ao equipamento de nossos estabelecimentos de ensino superior, notadamente daqueles destinados ao ensino técnico, é o mais precário possível.

Mas, não resta dúvida que a lacuna principal reside no pessoal docente e no corpo de pesquisadores sôbre os quais repousa em tôda parte o progresso técnico e científico. Parece inacreditável que nas Universidades, estabelecimentos de ensino e institutos de pesquisas e experimentação do Govêrno Federal ainda não foi instituído o regime do tempo integral. Um professor catedrático e um técnico ou pesquisador a serviço da União nada mais pode aspirar acima de um vencimento de 25.000 cruzeiros mensais no fim da carreira. Em conseqüência, são êles uns permanentes atormentados por problemas financeiros obrigados a dispersar tempo e energias no exercício de atividades, freqüentemente de importância secundária, a fim de obter meic para suplementar o minguado salário mensal. 
Outra falha visceral é a falta de incentivos aos jovens estudantes dq curso secundário capazes de os atrair para o estudo técnico ou para atividades de pesquisa científica. Não possuímos sistema org̨ nizado de bôlsas de estudos que permita procurar nos colégios os elementos mais bem dotados a fim de fornecer-ihes os meios necessários para que, no futuro, venham a integrar os quadros de cientistas e pesquisadores tão indispensáveis aos progressos adequados e permanentes à sua disposição, a fim de promover cursos de aperfeiçoamento no exterior para os que se distingam nos estudos universitários e para trazer sistemàticamente ao nosso país professôres e cientistas estrangeiros.

O Conselho Nacional de Pesquisas, cuja criação preencheu sensivel lacuna em nosso meio científico, vem realizando um esfôrço șilencioso e digno de nota no sentido da melhoria do nível da pesquisa técnica e científica em nosso $\mathrm{p} z$ ís. E' imprescindivel, todavia, que o Govêrno prestigie decididamente - Conselho e the conceda maiores recursos pois suas dotações bastante limitadas ainda têm sido parcialmente reduzidas pelos programas de economia orçamentárias.

A formação de técnicos, cientistas e pesquisadores em número adequado é condição esssencial para o desenvolvimento econômico de qualquer país e para a própria segurança nacional. De nada valerá consignar recursos orçamentários e levantar empréstimos para financiar êsse desenvolvimento se, paralelamente, não fôr constituído o "brain trust" capaz de orientá-lo e dirigi-lo científica e tècnicamente. O Brasil quer progredir e desenvolver-se dentro dos quadros da liberdade, da democracia, do respeito à dignidade humana $e$ sob a égide da iniciativa privada. A pesquisa técnica e científica, amparada e incentivada pelo Estado e pela emprêsa privada, deverá ser um dos pilares dêsse desenvolvimento. 